\title{
Long-term administration of intranasal insulin improves peripheral glucose concentration in diabetic male rats
}

\author{
Nihad Torabi $^{1,2}$, Maryam Nazari ${ }^{2}$, Javad Fahanik-Babaei ${ }^{3}$, Afsaneh Eliassi $^{1,2 *}$ iD \\ 1. Neurophysiology Research Center, Shahid Beheshti University of Medical Sciences, Tehran, Iran \\ 2. Department of Physiology, Medical School, Shahid Beheshti University of Medical Sciences, Tehran, Iran \\ 3. Neuroscience Research Center, Shahid Beheshti University of Medical Sciences, Tehran, Iran
}

\begin{abstract}
Introduction: Experiments in rodents and humans suggest that short-term intranasal insulin administration, which is known to reach the brain, does not affect peripheral glucose concentration under diabetic conditions.
\end{abstract}

Methods: In this work, we provide evidence for the effect of intranasal insulin (10 $\mathrm{IU} / \mathrm{rat} /$ day for 3 or 10 days) on serum insulin and glucose in streptozotocin-diabetic male rats using insulin measurements in the brain and periphery and a serum glucose assay 18 hours after three or ten days of nasal insulin administration.

Results: Our findings revealed peripheral insulin increased and glucose level decreased in the diabetic male rats. Based on insulin kinetics, it seems that brain insulin directly or indirectly regulates serum insulin and glucose metabolism under diabetic conditions.

Conclusion: Our results may suggest an insight into the therapeutic benefits of nasal insulin in diabetes.

\section{Keywords:}

Brain insulin;

Diabetes;

Intranasal insulin;

Peripheral insulin;

Peripheral glucose

* Corresponding author:

\section{A. Eliassi}

Email:

af.eliassi@sbmu.ac.ir

Tel: +9821-22439971

Received 5 February 2020;

Received in revised form 28

June 2020; Accepted 30 June

2020

http://dx.doi.org/10.32598/ppj.24.4.70

\section{Introduction}

Historically, it was assumed that insulin is a hormone that is present only in the periphery and is unable to cross the blood-brain barrier (Havrankova et al., 1978). But over the past few decades it has been considered that insulin is also found in the brain ( AJSzabo, 1983; Schechter et al., 1992). Brain insulin is primarily derived from pancreatic insulin and enters the brain via a saturable transport system (Banks, 2004; Banks et al., 1997; Baura et al., 1993; Pardridge et al., 1985; Schwartz et al., 1991). The idea that insulin can be synthesized in the brain is supported by several studies (Clarke et al., 1986; Deltour et al., 1993; Devaskar et al., 1994; Giddings et al., 1985; Mehran et al., 2012; Schechter et al., 1992; Young III, 1986). It is now well known that brain insulin plays important physiological roles in the central nervous system as well as the periphery (Derakhshan and Toth, 2013).

Peripheral glucose metabolism is regulated by the direct effects of insulin on organs. Furthermore, some studies in rodents have demonstrated that brain insulin suppressed endogenous (especially hepatic) glucose production (EGP) through a brain-liver axis 
(Filippi et al., 2012; Koch et al., 2008). In this regards, it has been observed that genetic manipulation of rodent brain insulin receptors can inhibit the suppression effect of brain insulin action on EGP (Koch et al., 2008; Könner et al., 2007). Therefore, the impaired ability of insulin in glucose uptake and suppression of EGP is a hallmark of type 2 diabetes (T2D) (Filippi et al., 2012; Koch et al., 2008; Lin and Accili, 2011).

Controversial studies reported that brain insulin concentration alters under diabetic conditions. For example, Havrankova et al. (1979) showed that insulin concentrations in the type 1 diabetes (T1D) rat brain were on average two and three times more than the controls, respectively; but the differences were not statistically significant when measured 1 week or 1 month after streptozotocin (STZ) treatment (Havrankova and Roth, 1979). Also, Sakamoto et al. (1980) found that the insulin content of the rat brain was not changed among fasting, T1D and control groups (Sakamoto et al., 1980). In contrast, Ruegsegger et al. (2019) found that brain insulin concentrations were reduced in T1D mice models (Ruegsegger et al., 2019). However, there are no studies on the level of insulin in the brain of T2D. In $\mathrm{T} 2 \mathrm{D}$, the evidence showed that a decrease in the activity of the brain insulin system led to an impairment of energy homeostasis and peripheral insulin sensitivity (Brüning et al., 2000) and was found to affect the metabolism of the periphery (Kullmann et al., 2016). Experimental T2D animal models have shown that brain and systemic insulin resistance are linked (Arnold et al., 2018). So, it is likely that brain and systemic complications of diabetes will be reduced by overcoming this resistance. Intranasal insulin provides an effective noninvasive approach to raise brain peptide concentrations (Born et al., 2002). It has been demonstrated that intranasal insulin administration lowered EGP in healthy humans (Dash et al., 2015). Intranasal insulin may therefore be a valuable treatment in diabetes. Although, it is worth noting that overweight men under hyperinsulinemia conditions did not show EGP suppression with a short-term treatment of intranasal insulin (106 IU) (Heni et al., 2017). Whether longer term administration of intranasal insulin affects peripheral glucose concentration in a T2D model remains to be determined. Thus, in this study we considered if long- term administration (10 days) of intranasal insulin is able to regulate peripheral glucose in type 2 diabetes. Furthermore, the serum insulin was assessed after using intranasal insulin (10 days) under diabetic and control conditions.

\section{Materials and methods}

\section{Animals}

Male wistar rats (Two-month-old; weighing 180-210g, $\mathrm{n}=6 /$ group; total number $=24$ ) were housed 3 per cage at room temperature $\left(22 \pm 2^{\circ} \mathrm{C}\right)$, a humidity of $50 \pm 10 \%$ and under standard $12 \mathrm{~h}$ light-dark cycle (the light period started at 7 A.M). Rats had free access to food and water ad libitum. Animal maintenance and treatment were in accordance with the National Institutes of Health Guidelines for the Care and Use of Laboratory Animals (National Institute of Health Publication No. 80-23, revised 1996) and approved by the Animal Ethics Committee of Shahid Beheshti University of Medical Sciences (IR.SBMU.MSP.REC. 1395.377). After one-week acclimation, the animals were randomly assigned to control+ saline $(C+S)$, diabetic+ saline $(D+S)$, control+ intranasal insulin $(\mathrm{C}+\mathrm{I})$ and diabetic+ intranasal insulin $(\mathrm{D}+\mathrm{l})$ groups.

\section{Diabetic animal model, measurement of serum insulin and glucose concentrations}

Diabetes was induced by a single intraperitoneal injection $(45 \mathrm{mg} / \mathrm{kg}$ body weight) of freshly prepared STZ (Sigma-Aldrich, St. Louis, Missouri, USA) in $0.1 \mathrm{M}$ citrate buffer $(\mathrm{pH} 4.5)$. Control animals were given an equal volume of citrate buffer. Serum glucose and insulin levels were checked on day 0 (before STZ injection) and also 7 and 14 days after STZ administration. Serum insulin was measured by rat insulin ELISA kit. Serum glucose was determined using the glucose oxidase method (Yuen and McNeill, 2000). Type 2 diabetes was confirmed by fasting serum glucose levels up to $180-200 \mathrm{mg} / \mathrm{dl}$ and increased serum insulin concentrations (Islam and Choi, 2007).

\section{Intranasal insulin delivery}

Intranasal delivery of insulin to the animal brain was performed as previously described by Thorne et al. (2004). Three days after STZ injection, insulin regular (Human, Recombinant DNA origin) was given intranasally at a dose of 10 units/rat/day until day 14 . Each rat was placed in a supine position and $50 \mu$ l of 
insulin was administered in each nostril with an Eppendorf pipette as $10 \mu \mathrm{l}$ drops every $1-2 \mathrm{~min}$ (once a day). Control animals were given an equal volume of saline.

\section{Brain insulin concentration determination}

Following decapitation, the animal's brain (6 rats/group) was removed and kept on ice during the whole dissection procedure. Next, a lysis buffer solution $(10 \mathrm{mM}$ Tris, $\mathrm{pH}=7.5, \quad 0.5 \%$ sodium deoxycholate, $100 \mathrm{mM} \mathrm{NaCl}, 100 \mathrm{mM}$ EDTA, protease inhibitor cocktail, $0.01 \%$ Triton $X 100$ ) was added to the brain tissue. After brain homogenizing, the suspension was centrifuged at $3500 \mathrm{~g}$ for $10 \mathrm{~min}$ at $4^{\circ} \mathrm{C}$ (Balbaa et al., 2017). Then, the supernatant was separated and transferred into a micro-tube and kept at $-80^{\circ} \mathrm{C}$. Lastly, an ultra-sensitive rat insulin ELISA kit (minimum detection: 0.02 $\mu \mathrm{g} /$; Mercodia, Sweden) was used to measure the brain insulin content.

\section{Statistical analysis}

All values from the animals were expressed as mean \pm SEM. Comparisons between the groups were done using a repeated measurement two-way ANOVA (to test serum glucose and insulin concentrations) followed by a Bonferroni post-hoc test and a one-way ANOVA (to test brain insulin levels) followed by Tukey's post-hoc test. $P<0.05$ was considered as statistically significant. All statistical tests reported in this study were done using the GraphPad Prism 5.0 (GraphPad Software, Inc., San Diego, CA).

A

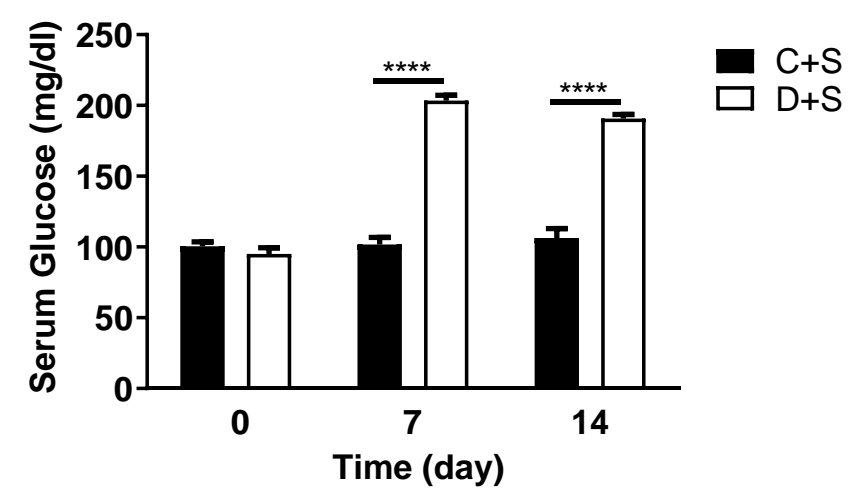

\section{Results}

\section{Serum glucose and insulin concentrations}

The rats serum insulin and glucose were measured after 7 and then 14 days of STZ injection. Using a two-way ANOVA, we found that fasting serum glucose levels significantly increased on days 7 and 14 after the injection of STZ compared to the control rats [treatment factor: $F(1,5)=351.6, P<0.0001$; time factor: $F(2,10)=166.2, \quad P<0.0001$; drug $\times$ time: $F(2$, $10)=202.8, \quad P<0.0001], \quad$ [standardised mean difference $(S M D)=1.41 ; 95 \% \mathrm{Cl}:-69.24$ to -52.54$]$. The respective values for fasting insulin concentrations was also found to be significantly elevated compared to the control rats [treatment factor: $F(1,5)=63.61, P=0.0005$; time factor: $F(2$, $10)=15.80, P=0.0008$; drug $\times$ time: $F(2,10)=16.07$, $P=0.0008], \quad[S M D=1.41 ; 95 \% \mathrm{Cl}:-1.14$ to -0.58 ] (Fig.1B).

\section{Insulin content in the brain}

Brain insulin concentrations in the STZ-treated animals $(31 \pm 2.7 \mathrm{ng} / \mathrm{ml})$ was significantly increased compared to the control rats $(12 \pm 0.38 \mathrm{ng} / \mathrm{ml})$, [SMD $=1.41 ; 95 \% \mathrm{Cl}:-36.39$ to $-1.612, P<0.05]$. We also found that intranasal insulin delivery increased the brain insulin approximately 12.5 and 6.5 times higher in the control $(150 \pm 8.3 \mathrm{ng} / \mathrm{ml}),[S M D=1.41$; 95\% Cl: -155.7 to $-120.9, P<0.0001]$ and diabetic $(203 \pm 0.15 \mathrm{ng} / \mathrm{ml}),[\mathrm{SMD}=1.41 ; 95 \% \mathrm{Cl}:-189.6$ to 154.8, $P<0.0001]$ groups, respectively, compared to the intranasal saline groups (Fig. 2).

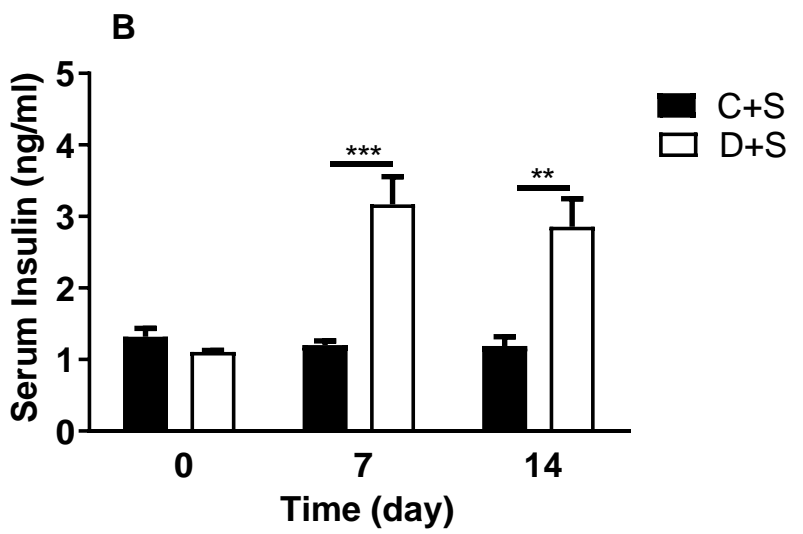

Fig.1. Serum fasting glucose and insulin concentration before the injection, 7 days, and 14 days after the injection of streptozotocin. Data are mean \pm SEM ( $n=6 /$ group). The statistical test of repeated measures two-way ANOVA showed a significant increase in fasting glucose $(A)$ and insulin $(B)$ concentrations on days 7 and 14 in the diabetic group compared to the control group. ${ }^{* *} P<0.01,{ }^{* * *} P<0.001,{ }^{* * *} P<0.0001$. 


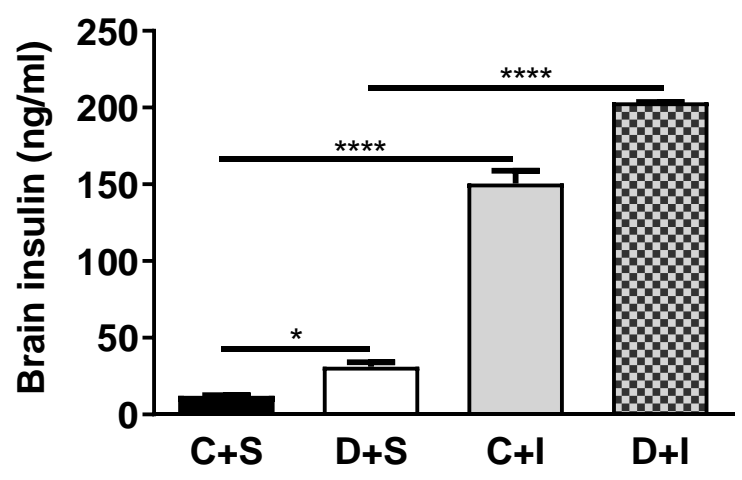

Fig.2. Insulin concentration in the rat brain. The insulin content of the brain in the diabetic group was higher than that of the control group. Intranasal administration of insulin increases levels of brain insulin in the both control and diabetes groups. Data are mean \pm SEM ( $n=6 /$ group). ${ }^{*} P<0.05,{ }^{* \star * *} P<0.0001$.

A

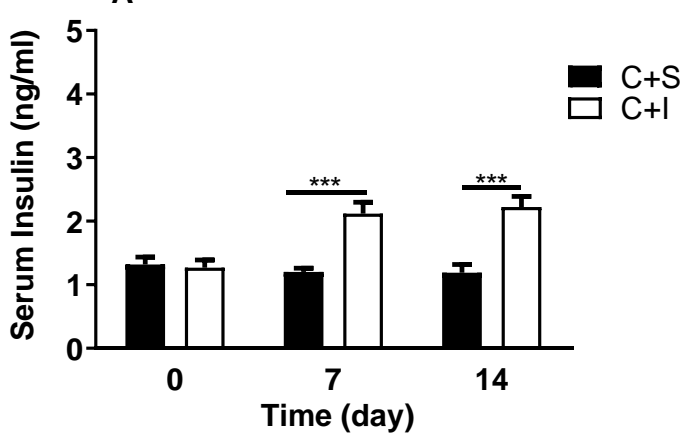

C

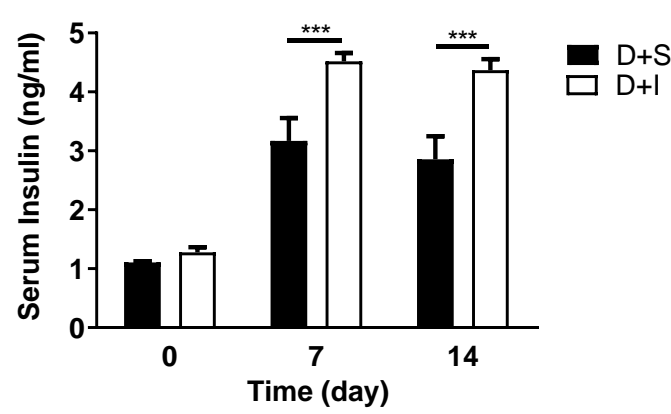

B

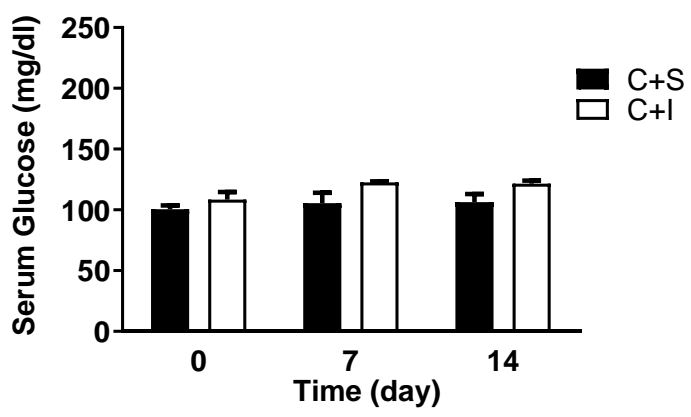

D

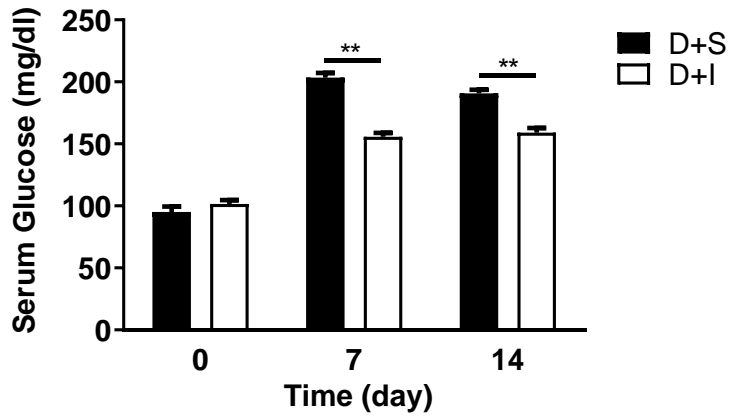

Fig.3. Concentration of insulin and glucose in serum after intranasal insulin delivery. Intranasal insulin administration increased serum insulin levels in the control group (A) but no changes in glucose levels are observed (B). In addition, intranasal insulin delivery in the diabetes group increased serum insulin levels (C) and reduced glucose levels (D). Data are mean \pm SEM (n=6/group). ${ }^{* *} P<0.01,{ }^{* * *} P<0.001$.

\section{Effect of intranasal insulin on serum glucose and} insulin concentrations

As shown in Figure 3A, intranasal insulin administration in the control group increased serum levels of insulin on days 7 and 14 compared to the intranasal saline group [treatment factor: $F(1,5)=$ 24.25, $P=0.0044$; time factor: $F(2,10)=19.73$, $P=0.0003$; drug $\times$ time: $F(2,10)=12.95, \quad P=0.0017]$,
[SMD $=1.41 ; 95 \% \mathrm{Cl}:-1.030$ to -0.3233$]$. However, serum glucose levels in these two groups did not show a significant difference [treatment factor: $F(1$, $5)=5.550, P=0.0651$; time factor: $F(2,10)=4.039$, $P=0.0518$; drug $\times$ time: $F(2,10)=0.1113, P=0.8957$ ], $[S M D=1.41 ; 95 \% \mathrm{Cl}:-20.68$ to 0.9014$]$ (Fig. 3B). Moreover, as shown in Figure $3 \mathrm{C}$, nasal insulin delivery in the diabetic group showed a significant 
increase in serum insulin concentration on days 7 and 14 after streptozotocin injection compared to the intranasal saline group [treatment factor: $F(1,5)=$ 28.30, $P=0.0031$; time factor: $F(2,10)=124.2$, $P<0.0001$; drug $\times$ time: $\mathrm{F}(2,10)=10.30, \quad P=0.0037]$, $[S M D=1.41 ; 95 \% \mathrm{Cl}:-1.346$ to -0.4690$]$. We also found that nasal insulin delivery in the diabetic group decreased serum glucose concentrations ( 25\%) compared to the intranasal saline group [treatment factor: $F(1,5)=39.02, P=0.0015$; time factor: $F(2$, $10)=686.1, P<0.0001 ;$ drug $\times$ time: $F(2,10)=9.464$, $P=0.0049$ ], [SMD=1.42; 95\% Cl: 7.978 to 19.13] (Fig. 3D).

\section{Discussion}

The current findings demonstrate that 1) long-term administration of intranasal insulin decreased peripheral glucose in diabetic rats but not in normal rats; 2) long-term administration of intranasal insulin increases the brain and serum insulin levels in the control and diabetes rats and 3 ) the brain insulin level increases significantly under early diabetic conditions. We found that the SMD between the groups was $\sim 1.41$.

Brain insulin plays the role of a neuroregulatory peptide in feeding behavior, energy storage (Benedict et al., 2008; Hallschmid et al., 2012), cognitive and memory functions (Craft et al., 2012). Insulin effects in the central nervous system (CNS) raise the question of whether CNS locally produces insulin. Rat and mouse brain RT-PCR study revealed the existence of insulin 2 mRNA (Devaskar et al., 1993; Mehran et al., 2012) and insulin gene expression in rabbit brain olfactory bulbs and hippocampal neurons confirmed brain insulin production (Devaskar et al., 1994). The above mentioned studies provided evidence for brain insulin production. It should be mentioned that although brain insulin mRNA expression and insulin peptide production have been reported, other studies have denied the evidence of insulin production in the brain (Adamo et al., 1989; Coker III et al., 1990; Devaskar et al., 1993; Woods et al., 2003). In the current study, brain and serum insulin concentrations were $\sim 12 \mathrm{ng} / \mathrm{ml}$ and $1.2 \mathrm{ng} / \mathrm{ml}$, respectively. Our work reported that rat brain insulin concentration was $\sim 10$ folds higher than serum insulin concentration. This is in line with the study by Havrankova et al. (1978) which showed the insulin concentration of the rat brain is $10-100$ times higher than that found in plasma.

Reduced brain cell sensitivity to insulin action has been defined as insulin resistance (Mielke et al., 2005) which could be due to insulin receptor downregulation, an inability of insulin to bind to receptors or an insulin signaling cascade impairment. In our experimental type 2 diabetes model, we observed that brain and serum insulin levels as compared to control groups were $\sim 31 \mathrm{ng} / \mathrm{ml}$ ( 3 folds increase) and $\sim 3.01 \mathrm{ng} / \mathrm{ml}$ ( 2.5 folds increases), respectively. It has been demonstrated that systemic insulin enters into the brain interstitial fluid through two selective and saturable transport system including the cerebrospinal fluid (CSF) and capillary endothelial cells of the blood-brain barrier. This transport system is impaired by a number of factors, including hyperglycaemia, diabetes mellitus, obesity and inflammation (Banks, 2004; Banks et al., 1997; Banks et al., 2012; Baura et al., 1993; Pardridge et al., 1985; Schwartz et al., 1991). Such findings raise the question of whether impaired insulin transport increases insulin resistance and T2D side effects (Freiherr et al., 2013). Our results indicate that a concentration gradient exists between brain and serum insulin concentrations in early T2D rats, with brain concentration being $\sim 10$-fold higher. One possible explanation is that a part of insulin found in the brain is derived from brain insulin production to compensate for impaired insulin signaling and hypometabolism. Clearly, this finding requires followup investigation. In this context, intranasal administration of insulin to raise brain insulin is a great hope. Intranasal delivery appears to increase brain insulin concentrations in animals (RamosRodriguez et al., 2017; Salameh et al., 2015) as well as humans (Born et al., 2002). Preliminary reports suggest that intranasal insulin use has a positive effects on memory and pathology in mice models (Chen et al., 2014; Zhang et al., 2016), but not in rat high fat diet-induced T2D (McNay et al., 2010). These results suggest that brain insulin resistance has developed and insulin treatment may not be sufficient to overcome resistance at a cellular level. Our results demonstrate that intranasal insulin delivery (10 $\mathrm{IU} / \mathrm{rat} /$ day for 3 or 10 days) raises the brain insulin roughly $\sim 12.5$ and 6.5 times higher in control and diabetic groups as compared to intranasal saline groups. Born et al. (2002) reported that intranasal regular human insulin (40 international unit) 
administration raised the CSF insulin concentration but did not affect serum concentration. In the current study, repeated intranasal insulin delivery increased serum insulin under diabetic condition $(\sim 1.5$ folds) in the control rats. In contrast, intranasal insulin decreased peripheral glucose concentration in the diabetes groups but not in the control groups. We did not observe a significant difference between 3 and 10 days of nasal insulin administration. It has been reported that a small amounts of insulin absorbs into the circulation shortly after large doses of intranasal insulin administration (Dash et al., 2015; Gancheva et al., 2015; Guthoff et al., 2010; Hallschmid et al., 2012; Heni et al., 2012; Heni et al., 2014), which may contribute in acute regulation of peripheral glucose metabolism and insulin sensitivity (Hallschmid et al., 2012; Heni et al., 2012; Heni et al., 2014). The peak plasma insulin level is seen $30-40 \mathrm{~min}$ after intranasal administration of insulin and decreases to baseline by 60min (Dash et al., 2015). In the current study, we measured serum insulin and glucose $18 \mathrm{~h}$ after intranasal insulin. In other words, when brain insulin concentration is high, peripheral insulin level will likely have declined to a basal concentration. Therefore, the increased insulin level in this study may suggest that insulin entered the brain via the nasal route directly or it may indirectly influence peripheral insulin level. In this regard, Heni et al. (2012) found an increase in hypothalamic activity that was related to an increased peripheral plasma level after nasal insulin spray in healthy human (about 20-30\%). We showed in this work that nasal insulin decreased peripheral glucose ( 25\%) under diabetic conditions. In previous works, brain insulin administration did not affect endogenous glucose production and glucose uptake in overweight (Heni et al., 2017) and in insulin resistant men (Xiao et al., 2018). Therefore, a lack of modulation of peripheral glucose might be associated with lowering the sensitivity in central insulin suppression of endogenous glucose production in insulin resistance. On the other hand, the time scales of this studies of intranasal insulin suggest that central insulin does not rapidly affect glucose production in the acute setting. As the current study shows, increasing brain insulin with longer-term (in several days instead of a few hours) administration may improve glucose metabolism under diabetic conditions. During intranasal insulin therapy, we measured the peripheral glucose on day 3 . Additional studies are also needed to evaluate the systemic glucose concentration on the first and second days as well as considering possibly insulin signaling in the liver in the context of brain insulin action under diabetic conditions.

\section{Conclusion}

We have provided preliminary evidence that longterm nasal insulin application decreased peripheral glucose concentration in diabetic rats. Our results may provide an insight into the therapeutic benefits of intranasal insulin in diabetes.

\section{Acknowledgments}

This work was supported by a grant from the Neurophysiology Research Center of Shahid Beheshti University of Medical Sciences.

\section{Conflict of interest}

The authors declare that there is no conflict of interest.

\section{References}

Adamo M, Raizada MK, LeRoith D. Insulin and insulin-like growth factor receptors in the nervous system. Mol Neurobiol 1989; 3: 71-100. https://doi.org/10.1007/ BF02935589

AJSzabo. CNS regulation of carbohydrate metabolism. Adv Metab Disord 1983; 10: 304-40.

Arnold SE, Arvanitakis Z, Macauley-Rambach SL, Koenig AM, Wang HY, Ahima RS, et al. Brain insulin resistance in type 2 diabetes and Alzheimer disease: concepts and conundrums. Nat Rev Neurol 2018; 14: 168-81. https://doi.org/10.1038/nrneurol.2017.185

Balbaa M, Abdulmalek SA, Khalil S. Oxidative stress and expression of insulin signaling proteins in the brain of diabetic rats: Role of Nigella sativa oil and antidiabetic drugs. PloS One 2017; 12: e0172429. https://doi.org/ 10.1371/journal.pone.0172429

Banks WA. The source of cerebral insulin. Eur J pharmacol 2004; 490: 5-12. https://doi.org/10.1016/j.ejphar.2004. 02.040

Banks WA, Jaspan JB, Huang W, Kastin AJ. Transport of insulin across the blood-brain barrier: saturability at euglycemic doses of insulin. Peptides 1997; 18: 1423-9. https://doi.org/10.1016/S0196-9781(97)00231-3

Banks WA, Owen JB, Erickson MA. Insulin in the brain: there and back again. Pharmacol Ther 2012; 136: 8293. https://doi.org/10.1016/j.pharmthera.2012.07.006

Baura GD, Foster DM, Porte D, Kahn SE, Bergman RN, Cobelli $C$, et al. Saturable transport of insulin from plasma into the central nervous system of dogs in vivo. A mechanism for regulated insulin delivery to the brain. 
J Clin Invest 1993; 92: 1824-30. https://doi.org/10.1172/ JCl116773

Benedict C, Kern W, Schultes B, Born J, Hallschmid M. Differential sensitivity of men and women to anorexigenic and memory-improving effects of intranasal insulin. J Clin Endocrinol Metab 2008; 93: 1339-44. https://doi.org/10.1210/jc.2007-2606

Born J, Lange T, Kern W, McGregor GP, Bickel U, Fehm HL. Sniffing neuropeptides: a transnasal approach to the human brain. Nat Neurosci 2002; 5: 514-6. https://doi.org/10.1038/nn0602-849

Brüning JC, Gautam D, Burks DJ, Gillette J, Schubert M, Orban PC, et al. Role of brain insulin receptor in control of body weight and reproduction. Science 2000; 289 : 2122-5. https://doi.org/10.1126/science.289.5487.2122

Chen Y, Zhao Y, Dai C-I, Liang Z, Run X, lqbal K, et al. Intranasal insulin restores insulin signaling, increases synaptic proteins, and reduces $A \beta$ level and microglia activation in the brains of $3 \times \mathrm{Tg}-\mathrm{AD}$ mice. Exp Neurol 2014; 261: 610-9. https://doi.org/10.1016/j.expneurol. 2014.06.004

Clarke DW, Mudd L, Boyd Jr FT, Fields M, Raizada MK. Insulin is released from rat brain neuronal cells in culture. J Neurochem 1986; 47: 831-836. https://doi.org/ 10.1111/j.1471-4159.1986.tb00686.x

Coker III GT, Studelska D, Harmon S, Burke W, O'Malley $\mathrm{KL}$. Analysis of tyrosine hydroxylase and insulin transcripts in human neuroendocrine tissues. Brain Res Mol Brain Res 1990; 8: 93-98. https://doi.org/ 10.1016/0169-328X(90)90052-F

Craft S, Baker LD, Montine TJ, Minoshima S, Watson GS, Claxton A, et al. Intranasal insulin therapy for Alzheimer disease and amnestic mild cognitive impairment: a pilot clinical trial. Arch Neurol 2012; 69: 29-38. https://doi.org/10.1001/archneurol.2011.233

Dash S, Xiao C, Morgantini C, Koulajian K, Lewis GF. Intranasal insulin suppresses endogenous glucose production in humans compared with placebo in the presence of similar venous insulin concentrations. Diabetes 2015; 64: 766-74. https://doi.org/10.2337/ db14-0685

Deltour L, Leduque P, Blume N, Madsen O, Dubois P, Jami $J$, et al. Differential expression of the two nonallelic proinsulin genes in the developing mouse embryo. Proc Natl Acad Sci USA 1993; 90: 527-31. https://doi.org/ 10.1073/pnas.90.2.527

Derakhshan F, Toth C. Insulin and the brain. Curr Diabetes Rev 2013; 9: 102-16. https://doi.org/10.2174/ 1573399811309020002

Devaskar SU, Giddings SJ, Rajakumar PA, Carnaghi LR, Menon RK, Zahm DS. Insulin gene expression and insulin synthesis in mammalian neuronal cells. J Biol Chem 1994; 269: 8445-54.

Devaskar SU, Singh BS, Carnaghi LR, Rajakumar PA, Giddings SJ. Insulin II gene expression in rat central nervous system. Regul Pept 1993; 48: 55-63. https://doi.org/10.1016/0167-0115(93)90335-6

Filippi BM, Yang CS, Tang C, Lam TK. Insulin activates Erk1/2 signaling in the dorsal vagal complex to inhibit glucose production. Cell Metab 2012; 16: 500-10. https://doi.org/10.1016/j.cmet.2012.09.005

Freiherr J, Hallschmid M, Frey WH, Brünner YF, Chapman $\mathrm{CD}$, Hölscher $\mathrm{C}$, et al. Intranasal insulin as a treatment for Alzheimer's disease: a review of basic research and clinical evidence. CNS Drugs 2013; 27: 505-14. https://doi.org/10.1007/s40263-013-0076-8

Gancheva S, Koliaki C, Bierwagen A, Nowotny P, Heni M, Fritsche $A$, et al. Effects of intranasal insulin on hepatic fat accumulation and energy metabolism in humans. Diabetes 2015; 64: 1966-75. https://doi.org/10.2337/ db14-0892

Giddings SJ, Chirgwin J, Permutt MA. Evaluation of rat insulin messenger RNA in pancreatic and extrapancreatic tissues. Diabetologia 1985; 28: 343-7. https://doi.org/10.1007/BF00283141

Guthoff M, Grichisch Y, Canova C, Tschritter O, Veit R, Hallschmid $M$, et al. Insulin modulates food-related activity in the central nervous system. J Clin Endocrinol Metab 2010; 95: 748-55. https://doi.org/10.1210/ jc.2009-1677

Hallschmid M, Higgs S, Thienel M, Ott V, Lehnert $H$. Postprandial administration of intranasal insulin intensifies satiety and reduces intake of palatable snacks in women. Diabetes 2012; 61: 782-9. https://doi.org/10.2337/db11-1390

Havrankova J, Roth J. Concentrations of insulin and of insulin receptors in the brain are independent of peripheral insulin levels: studies of obese and streptozotocin-treated rodents. J Clin Invest 1979; 64: 636-42.https://doi.org/10.1172/JCl109504

Havrankova J, Schmechel D, Roth J, Brownstein M. Identification of insulin in rat brain. Proc Natl Acad Sci USA 1978; 75: 5737-41. https://doi.org/10.1073/ pnas.75.11.5737

Heni M, Kullmann S, Ketterer C, Guthoff M, Linder K, Wagner $R$, et al. Nasal insulin changes peripheral insulin sensitivity simultaneously with altered activity in homeostatic and reward-related human brain regions. Diabetologia 2012; 55: 1773-82. https://doi.org/10.1007/ s00125-012-2528-y

Heni M, Wagner R, Kullmann S, Gancheva S, Roden M, Peter A, et al. Hypothalamic and striatal insulin action suppresses endogenous glucose production and may stimulate glucose uptake during hyperinsulinemia in lean but not in overweight men. Diabetes 2017; 66: 1797-806. https://doi.org/10.2337/db16-1380

Heni M, Wagner R, Kullmann S, Veit R, Husin HM, Linder $\mathrm{K}$, et al. Central insulin administration improves wholebody insulin sensitivity via hypothalamus and parasympathetic outputs in men. Diabetes 2014; 63: 4083-8. https://doi.org/10.2337/db14-0477

Islam MS, Choi H. Nongenetic model of type 2 diabetes: a comparative study. Pharmacol 2007; 79: 243-9. https://doi.org/10.1159/000101989

Koch L, Wunderlich FT, Seibler J, Könner AC, Hampel B, Irlenbusch $S$, et al. Central insulin action regulates peripheral glucose and fat metabolism in mice. J Clin Invest 2008; 118: 2132-47. https://doi.org/10.1172/ 


\section{$\mathrm{JCl} 31073$}

Könner AC, Janoschek R, Plum L, Jordan SD, Rother E, $\mathrm{Ma} X$, et al. Insulin action in AgRP-expressing neurons is required for suppression of hepatic glucose production. Cell Metab 2007; 5: 438-49. https://doi.org/ 10.1016/j.cmet.2007.05.004

Kullmann S, Heni M, Hallschmid M, Fritsche A, Preiss $H$, Häring $\mathrm{HU}$. Brain insulin resistance at the crossroads of metabolic and cognitive disorders in humans. Physiol Rev 2016; 96: 1169-209. https://doi.org/10.1152/ physrev.00032.2015

Lin HV, Accili D. Hormonal regulation of hepatic glucose production in health and disease. Cell Metab 2011; 14: 9-19. https://doi.org/10.1016/j.cmet.2011.06.003

McNay EC, Ong CT, McCrimmon RJ, Cresswell J, Bogan JS, Sherwin RS. Hippocampal memory processes are modulated by insulin and high-fat-induced insulin resistance. Neurobiol Learn Mem 2010; 93: 546-53. https://doi.org/10.1016/j.nlm.2010.02.002

Mehran AE, Templeman NM, Brigidi GS, Lim GE, Chu KY, $\mathrm{Hu} X$, et al. Hyperinsulinemia drives diet-induced obesity independently of brain insulin production. Cell Metab 2012; 16: 723-37. https://doi.org/10.1016/j.cmet. 2012.10.019

Mielke JG, Taghibiglou C, Liu L, Zhang Y, Jia Z, Adeli K, et al. A biochemical and functional characterization of dietinduced brain insulin resistance. J Neurochem 2005; 93: 1568-78. https://doi.org/10.1111/j.1471-4159.2005. 03155.x

Pardridge WM, Eisenberg J, Yang J. Human blood brain barrier insulin receptor. J Neurochem 1985; 44: 1771-8. https://doi.org/10.1111/j.1471-4159.1985.tb07167.x

Ramos-Rodriguez JJ, Sanchez-Sotano D, Doblas-Marquez A, Infante-Garcia C, Lubian-Lopez S, Garcia-Alloza M. Intranasal insulin reverts central pathology and cognitive impairment in diabetic mother offspring. Mol Neurodegener 2017; 12: 1-4. https://doi.org/10.1186/ s13024-017-0198-4

Ruegsegger GN, Manjunatha S, Summer P, Gopala S, Zabeilski $P$, Dasari $S$, et al. Insulin deficiency and intranasal insulin alter brain mitochondrial function: a potential factor for dementia in diabetes. FASEB $\mathrm{J}$ 2019; 33: 4458-72. https://doi.org/10.1096/fj. 201802043R

Sakamoto Y, Oomura Y, Kita H, Shibata S, Suzuki S,
Kuzuya $T$, et al. Insulin content and insulin receptors in the rat brain. Effect of fasting and streptozotocin treatment. Biomed Res 1980; 1: 334-40. https://doi.org/10.2220/biomedres.1.334

Salameh TS, Bullock KM, Hujoel IA, Niehoff ML, WoldenHanson T, Kim J, et al. Central nervous system delivery of intranasal insulin: mechanisms of uptake and effects on cognition. J Alzheimer's Dis 2015; 47: 715-28. https://doi.org/10.3233/JAD-150307

Schwartz MW, Bergman RN, Kahn SE, Taborsky GJ, Fisher LD, Sipols AJ, et al. Evidence for entry of plasma insulin into cerebrospinal fluid through an intermediate compartment in dogs. Quantitative aspects and implications for transport. J Clin Invest 1991; 88: 127281. https://doi.org/10.1172/JCl115431

Schechter R, Whitmire J, Holtzclaw L, George M, Harlow R, Devaskar SU. Developmental regulation of insulin in the mammalian central nervous system. Brain Res 1992; 582: 27-37. https://doi.org/10.1016/0006-8993(92) 90313-X

Thorne RG, Pronk GJ, Padmanabhan V, Frey li WH. Delivery of insulin-like growth factor-I to the rat brain and spinal cord along olfactory and trigeminal pathways following intranasal administration. Neuroscience 2004; 127: 481-96. https://doi.org/10.1016/j.neuroscience. 2004.05.029

Woods SC, Seeley RJ, Baskin DG, Schwartz MW. Insulin and the blood-brain barrier. Curr Pharm Des 2003; 9: 795. https://doi.org/10.2174/1381612033455323

Xiao C, Dash S, Stahel P, Lewis GF. Effects of intranasal insulin on endogenous glucose production in insulinresistant men. Diabetes Obes Metab 2018; 20: 1751-4. https://doi.org/10.1111/dom.13289

Young III WS. Periventricular hypothalamic cells in the rat brain contain insulin mRNA. Neuropeptides 1986; 8: 9397. https://doi.org/10.1016/0143-4179(86)90035-1

Yuen VG, McNeill JH. Comparison of the glucose oxidase method for glucose determination by manual assay and automated analyzer. J Pharmacol Tox Met 2000; 44: 543-6. https://doi.org/10.1016/S1056-8719(01)00117-4

Zhang Y, Dai Cl, Chen Y, lqbal K, Liu F, Gong CX. Intranasal insulin prevents anesthesia-induced spatial learning and memory deficit in mice. Sci Rep 2016; 6. https://doi.org/10.1038/srep21186 